Website: ijetms.in Issue:6, Volume No.4, September-2020 DOI: 10.46647/ijetms.2020.v04i06.007

\title{
A study on online shopping vs offline shopping with reference to the students of the Department of Commerce and Management Studies, Andhra University, Visakhapatnam.
}

\author{
A.Lakshmipriyanka ${ }^{1}$, M.Harihararao ${ }^{2}$ \\ ${ }^{1}$ Research Scholar, DCMS Andhra University, Visakhapatnam, A.P. \\ ${ }^{2}$ Library Assistant, MVGR College of Engineering (A),Vizianagaram, A.P. \\ 1'lakshmipriyankaa@gmail.com \\ 2harihararao21@gmail.com
}

\begin{abstract}
:
The Aim of this research is to study the factors affecting the consumer behavior in the path of offline to online shopping. To this end, a survey was conducted and the questionnaires were distributed among the students of the university. The replies have been analyzed by chart analysis. The results of the survey has shown that most of the people already doing online shopping and prefer to continue it.the factors such as psychological factors, social factors emotional factors, and the privacy factors which affect the buyer approaches to online purchases. Several attitudes of consumers toward online shopping are not in rest in the study due to the study restricted to Andhra university-Commerce and management Time, the convenience and the recommendations have been identified as important factors. Time was considered to be the affecting factor for the majority of students. Most of the consumers hesitate not to do shopping offline, because of the time concern.
\end{abstract}

Key words: buying behavior, online shopping

\section{Introduction:}

Past few years there is a significant change in consumer buying behavior. Consumers are ready to upgrade their life style, selectionof brand and preferences. Availability of smart phones is impacting on online buying behavior. Consumers have variety of options to buy like online shopping and offline shopping. Number of online shopping applications has been increased past few years. Consumers have convenient time to do shopping. Usage of internet, making a habit of online shopping regularly.This study examines the consumer buying behavior of online shopping versus offline shopping.

Online shopping has made asignificant change in global marketing. Marketers changed their strategies towards buyers. Consumers also changed narrow way of shopping to broader sense. Variety of products increased and time decreased. Availability of products form long distances on a single step made application. everyone has a basic knowledge about online 
Website: ijetms.in Issue:6, Volume No.4, September-2020 DOI: 10.46647/ijetms.2020.v04i06.007

shopping. It became a habit of daily life. So many surveys made on online shopping impacting on consumers. Number of applications increased for online, seasonal offers increased comparing to offline shopping. Convenience time is a basic for creating more interest on online shopping. Prompt of shopping done daily by messages and notifications. Recently affiliated apps also making more availability of product reducing consumer's time that spent on a particular product. So many factors are affecting online shopping like psychological, social, economic etc., Here my study is limited to the students of the Department of Commerce and Management, Andhra University, Visakhapatnam, Andhra Pradesh. There is a comparison among different cultures impacting on buying behavior.

\section{Review of literature:}

Sharma, A. and Sheth, J. N. $\left(2004^{1}\right)$ have discussed the implication of internet on market theory and practices. In the web based era, marketing will be seen as an assetand heavy in technology will reduce transaction cost. Internet is more customersfocused as compared to traditional marketing. Further, the study focused on theconcept of co-creation which means the customer-firm interaction. It will help bothi.e. customer as well as marketer.

Dahiya, $R$. $(2012)^{2}$ has mentioned that online shopping is very common outside Indiabut its growth in Indian market still not in line with the global market. Further, studyrevealed that demographic factors show that gender has a positive impact onfrequency of online shopping and family size has impact on overall expenditure onon-line shopping. Finally, it is concluded that customer has positive response towardsonline shopping
Reddy, K.S. and Jayalaxmi, S. (201432 revealed that time saving, cost saving,variety of products, $24 \mathrm{x} 7$ Shopping facility, attractive gifts and discounts attractscustomers towards online shopping but there are other factors such as delay indelivery process, lack of sufficient information about the product and lack of privacywhich proves to be hurdle in online shopping.

Pandey, B. B., Barik, P. and Soni, V. $(2015)^{4}$ reveals that time, cost, discount, offers, variety of products, home delivery and word of mouth publicity are main

features of online shopping which attracts consumers. Study also found out that malesare more ahead in shopping as compare to females. All development in e-shopping isbecause of updated technology.

Kumar, A., Kumar, S. and Gunasekaran, A. $(2017)^{5}$ has focused on thedeterminants that are affecting the online purchase behaviour of millennialconsumers. The study found that there is positive relationship between websitedesign, layout and user interface which helped in searching and choosing right kind ofproduct while purchasing online.

Zhang, H., Zhao, L., and Gupta, S. $(2018)^{6}$ found that consumer product screeningcost and decision making quality have significant influence on consumer loyaltywhereas product screening cost is negatively associated with self-reference and positively associated with deceptiveness and information overload.

Chandan, $A^{7}$ Buying Behaviourof the ultimate consumer. Many factors, specificities and characteristics influence the individual in what he is and the consumer in his decision making process, shopping habits, purchasing behavior, the brands he buys or the retailers he goes. 
Website: ijetms.in Issue:6, Volume No.4, September-2020 DOI: 10.46647/ijetms.2020.v04i06.007

\section{Objectives of the Study:}

1. To measure the awareness about online shopping in Andhra University students.

2. To study the factors of online shopping between male and female.

3. To analyze the factors that influence online versus offline shopping.

Scope of the study:

The importance of the study is to know about the buying behavior of Andhra University students towards shopping. It has been recognized in academic research and its literature. This study is limited to students of the department of Commerce and Management studies Andhra University, Visakhapatnam, Andhra Pradesh.

\section{Research methodology:}

The research is purely based on primary data and the data has collected through a questionnaire designed exclusively for the study. The questionnaire was designed to collect information about demographic profile of the respondents such as age, gender, education and family monthly income. In addition to this various questions related to the knowledge and experience about online shopping, reason for choosing online shopping, type of products purchased online, factors affecting consumer's behavior while online shopping etc.

Secondary data was collected from research papers, Journals, magazines and websites.

\section{Sample size:}

Sample was collected from Andhra University student's buyers of online shopping. The questionnaires were entertained by around 100 respondents.

\section{Statistical Tools:}

Demographic analysis:

Table: I

\begin{tabular}{|c|c|c|c|}
\hline $\begin{array}{l}\mathrm{S} . \\
\mathrm{N} \\
\mathrm{O}\end{array}$ & $\begin{array}{l}\text { Character } \\
\text { is-tics }\end{array}$ & Category & $\begin{array}{l}\text { Frequen } \\
\text { cy }\end{array}$ \\
\hline \multirow[t]{2}{*}{1} & \multirow{2}{*}{ Gender } & Male & 61 \\
\hline & & Female & 39 \\
\hline \multirow[t]{3}{*}{2} & \multirow{3}{*}{ Age } & $20-25$ years & 80 \\
\hline & & $25-30$ years & 15 \\
\hline & & $30-35$ years & 5 \\
\hline \multirow[t]{2}{*}{3} & \multirow{2}{*}{$\begin{array}{l}\text { Educatio } \\
\mathrm{n} \\
\text { Qualifica } \\
\text { tion }\end{array}$} & $\begin{array}{l}\text { Post- } \\
\text { graduation }\end{array}$ & 83 \\
\hline & & Ph.D. & 17 \\
\hline \multirow[t]{4}{*}{4} & \multirow{4}{*}{$\begin{array}{l}\text { Family } \\
\text { Income }\end{array}$} & $\begin{array}{l}\text { Rs. } 20,000 \\
\text { - Rs. } 25,000 \\
\end{array}$ & 30 \\
\hline & & $\begin{array}{l}\text { Rs. } 25,000 \\
\text { - Rs. } 30,000\end{array}$ & 40 \\
\hline & & $\begin{array}{l}\text { Rs. } 30,000 \\
\text { - Rs. } 35,000\end{array}$ & 15 \\
\hline & & $\begin{array}{l}\text { Rs. } 35,000 \\
\text { - Rs. } 40,000\end{array}$ & 15 \\
\hline \multirow[t]{2}{*}{5} & \multirow{2}{*}{$\begin{array}{l}\text { Marital } \\
\text { status }\end{array}$} & Single & 85 \\
\hline & & Married & 15 \\
\hline
\end{tabular}

Source: data collected from questionnaire

Interpretation:Table illustrate that $61 \%$ of Male and 39\% of Female respondents participated in this survey. The age group of 20-25 years participated 80\%,25-30 years participated $15 \%$ and 30-35 years participated $5 \%$.Majority of students are ( $83 \%$ ) post graduates and remaining(17\%)Ph.D. students $.70 \%$ of respondents are havingbelow Rs.30000, 30\% respondents having below Rs.40000 income level. 85\% respondents are single and $15 \%$ respondents are married. 
Website: ijetms.in Issue:6, Volume No.4, September-2020 DOI: 10.46647/ijetms.2020.v04i06.007

\section{Attitude towards online} shopping:

Table II:

\begin{tabular}{|l|l|l|l|}
\hline $\begin{array}{l}\text { Gende } \\
\text { r }\end{array}$ & $\begin{array}{l}\text { Posi } \\
\text { tive } \\
\text { attit } \\
\text { ude }\end{array}$ & $\begin{array}{l}\text { Neg } \\
\text { ative } \\
\text { attitu } \\
\text { de }\end{array}$ & $\begin{array}{l}\text { Neut } \\
\text { ral } \\
\text { attitu } \\
\text { de }\end{array}$ \\
\hline Male & 60 & 1 & 0 \\
\hline $\begin{array}{l}\text { Femal } \\
\text { e }\end{array}$ & 35 & 4 & 0 \\
\hline
\end{tabular}

Interpretation: According to the analysis there is a positive attitude towards online shopping $95 \%(60 \%$ male \& $35 \%$ female) of respondents. Only $5 \%$ of students have negative attitude.

Mode of shopping:

Table III:

\begin{tabular}{|l|l|l|l|}
\hline Gender & Online & Offline & Both \\
\hline Male & 11 & 10 & 40 \\
\hline Female & 5 & 14 & 20 \\
\hline
\end{tabular}

Interpretation:From the survey $40 \%$ of male and $20 \%$ female respondents are interested to do both offline and online shopping. Offline shopping is interested by $10 \%$ of male and $14 \%$ female. Online shopping is interested by $11 \%$ male and $5 \%$ female respondents.
Frequency of shopping:

Table IV:

\begin{tabular}{|l|l|l|}
\hline Frequency & Offline & Online \\
\hline Daily & 0 & 0 \\
\hline Twice a weak & 2 & 5 \\
\hline Once in aweak & 12 & 24 \\
\hline $\begin{array}{l}\text { Twice in a } \\
\text { month }\end{array}$ & 22 & 20 \\
\hline $\begin{array}{l}\text { Once in a } \\
\text { month }\end{array}$ & 34 & 30 \\
\hline $\begin{array}{l}\text { Once in 2 } \\
\text { months }\end{array}$ & 30 & 21 \\
\hline
\end{tabular}

Interpretation:According to frequency of shopping offline shopping made once in a month or more is $64 \%$, lessthan a month is $36 \%$. For online shopping, frequency is $51 \%$ above a month and $49 \%$ is less than a month. There is no frequency regular shopping for both online and offline.

Online shopping made with Concern app vs affiliated marketing app:

Table V:

\begin{tabular}{|l|l|l|}
\hline Gender & $\begin{array}{l}\text { Concern app } \\
\text { (amazon, } \\
\text { Flip kart etc... } \\
\text { ) }\end{array}$ & Affiliated app \\
\hline Male & 40 & 21 \\
\hline Female & 25 & 14 \\
\hline
\end{tabular}

Interpretation: According to survey concern application based shopping done by male is $40 \%$ and female is $25 \%$. In recent times affiliated marketing applications also making a dominant role.by that affect the frequency of shopping through affiliated marketing applications is $21 \%$ male and $14 \%$ female. 
Website: ijetms.in Issue:6, Volume No.4, September-2020 DOI: 10.46647/ijetms.2020.v04i06.007

Factors of online shopping(Ranking)

Table VI:

\begin{tabular}{|l|l|l|}
\hline Factors & Male & Female \\
\hline Time saving & 1 & 1 \\
\hline Availability & 4 & 4 \\
\hline $\begin{array}{l}\text { Home delivery } \\
\text { and Return } \\
\text { policy }\end{array}$ & 5 & 5 \\
\hline $\begin{array}{l}\text { Better price and } \\
\text { offers }\end{array}$ & 2 & 3 \\
\hline $\begin{array}{l}\text { Variety of } \\
\text { products }\end{array}$ & 3 & 2 \\
\hline Easy to access & 6 & 6 \\
\hline Credit facility & 7 & 7 \\
\hline
\end{tabular}

Interpretation: Correlation of male and female about online shopping is showing a positive impact in the survey like time is ranked as $1^{\text {st }}$ constraint for online shopping followed by better price and variety of products ranked a difference between male and female concern, remaining factors like availability, delivery, return, easy to access and credit facility followed by reaming ranks up to 7 .

Reasons to choose offline shopping:

Table VII:

\begin{tabular}{|l|l|l|}
\hline Reasons & Male & Female \\
\hline $\begin{array}{l}\text { Tangible } \\
\text { product }\end{array}$ & 1 & 1 \\
\hline Trail and select & 2 & 2 \\
\hline Bargaining & 5 & 3 \\
\hline $\begin{array}{l}\text { Immediate } \\
\text { delivery }\end{array}$ & 3 & 4 \\
\hline Loyalty & 4 & 7 \\
\hline Return & 6 & 5 \\
\hline $\begin{array}{l}\text { Coupons and } \\
\text { discounts }\end{array}$ & 7 & 6 \\
\hline
\end{tabular}

\section{Interpretation:}

The factors to choose offline shopping is ranked as tangible product (feel and touch) is $1^{\text {st }}$ rank followed by trail and select as $2^{\text {nd }}$ place. Male point of view loyalty, bargaining, returns, coupons followed by $3^{\text {rd }}$ to $7^{\text {th }}$ rank. Female point of view bargaining, immediate delivery, return, coupons, loyalty followed by $3^{\text {rd }}$ to $7^{\text {th }}$ rank.

\section{Findings \& conclusion:}

$>$ Most of the respondents are aware about online shopping.

$>$ Everyone is ready to adapt new culture and style.

$>$ Time is a major constraint of shopping.

$>$ Convenience to shopping is prompt to buy products online.

$>$ Offline shopping is not done regularly.

$>$ Affiliated applications are

impacting psychological factor to buy from the peer group online products.

\section{References:}

[1]. Sharma, a., and Sheth, j. N. (2004). Web based marketing: the upcomingRevolution in marketing thought and strategy. Journal of business research, Vol. 57, pp. 696-702

[2]. Dahiya, r. (2012). Impact of demographic factors of consumers on onlineShopping behaviour: a study of consumers in india. International journal of

Engineering and management science, vol. 3 (issue 1), pp. 43-52.

[3]. Reddy, k. L., and Jayalaxmi, s. (dec. 2014). A comperative study of 
Website: ijetms.in Issue:6, Volume No.4, September-2020 DOI: 10.46647/ijetms.2020.v04i06.007

traditionalShopping vs online shopping.Www.stannsannquest.com

[4]. Pandey, b. B., barik, p., and soni, v. (2015). Online shopping catching up fastWith the trend- chhattisgarh context. International journal of research in commerce and management, vol. 6 (no. 4), pp. 53-57.

[5]. Kumar, a., kumar, s. And gunasekaran, a. (2017).An empirical study on the factors affecting online shopping behavior of millennial consumers.Journal ofInternet commerce, vol. 16 (no. 3), pp. 219-230.

[6]. Zhang, h., zhao, 1., and gupta, s. (2018). The role of online product recommendations on customer decision making and loyalty in social shopping

Communities. International journal of information management, vol. 38, pp.150-166.

[7]. Chandan,A. MBA, NET., planning executive in aquarelle indiapvt ltd (textile company). International journal of advanced research (IJAR). 